[Agr. Biol. Chem., Vol. 36, No. 5, p. 893 895, 1972]

\title{
Studies on the Lipase of Thermophilic Fungus Humicola lanuginosa
}

Sir:

The industrial production of the enzyme by thermophilic microorganisms has been reported only in a few case. The interests of those investigators were focussed on $\alpha$-amylase and protease from Actomycetes and Bacillus. ${ }^{1 \sim 4}$ Although the industrial production of lipase (EC 3.1.1.3) by microorganisms has aroused a considerable interest of many microbiologists $^{5 \sim 11)}$ during the past decade, the production of lipase by thermophilic microorganisms has not been reported. The present investigation was undertaken as a basic research for the enzyme properties and development of utilization of lipase.

From compost soil samples collected in the vicinity of Tokyo, we have isolated a thermophilic fungus which could produce a remarkable amount of thermostable, alkalistable and extracellular lipase. The taxonomical characteristics of this thermophilic fungus were examined and the fungus was identified as Humicola lanuginosa S-38. The thermophilic fungus was cultivated with aeration at $45^{\circ} \mathrm{C}$ for $80 \mathrm{hr}$ on

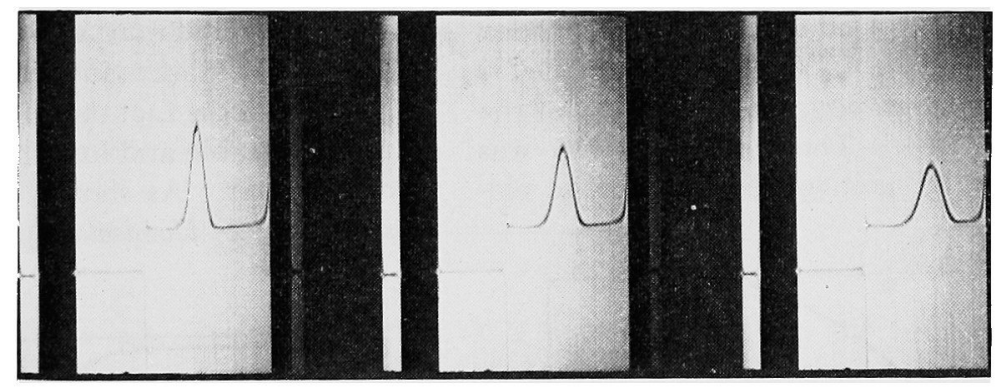

$10 \mathrm{~min}$

$20 \mathrm{~min}$

$30 \mathrm{~min}$

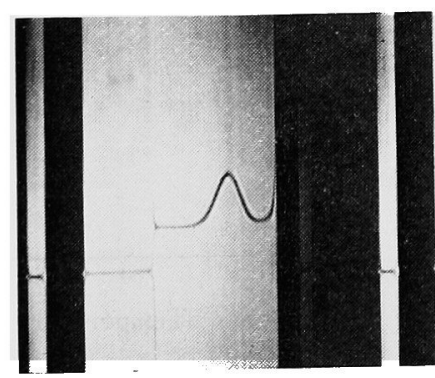

$40 \mathrm{~min}$

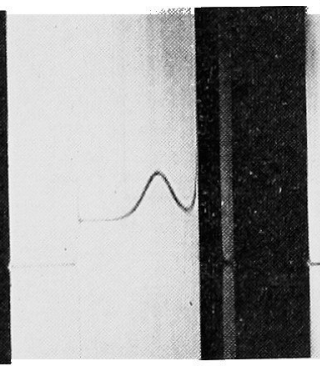

$50 \mathrm{~min}$
$60 \mathrm{~min}$

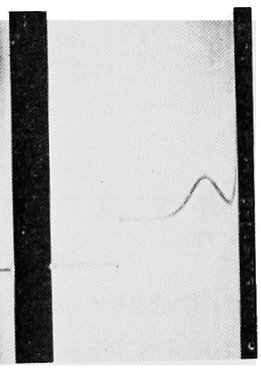

FIG. 1. Ultra-centrifuge Patterns of Humicola Lipase.

Data: Enzyme concentration $=0.750 ; 0.05 \mathrm{M}$ Tris-HCl buffer $(\mathrm{pH} 8.0)$ contained $0.1 \mathrm{M} \mathrm{KCl}$; Synthetic boundary cell, $60,000 \mathrm{rev} . / \mathrm{min}, 25^{\circ} \mathrm{C}$. 
a medium consisting of $2.0 \%$ soluble starch, $5.0 \%$ corn steep liquor, $0.2 \% \mathrm{~K}_{2} \mathrm{HPO}_{4}, 0.1 \%$ $\mathrm{MgSO}_{4} \cdot 7 \mathrm{H}_{2} \mathrm{O}, 0.50_{0}^{\circ}$ soybean oil, 0.00506 deforming agent (Adecanol LG-109) in a 600 liter stainlesssteal fermenter. The cultured broth was filtered to remove cells and the filtrate was precipated with ammonium sulfate at $600^{\circ}$ saturation. The precipitate was collected by centrifugation and desalted by dialyzing against distilled water for $48 \mathrm{hr}$ at $5^{\circ} \mathrm{C}$. Then the dialyzed enzyme solution was lyophilized.

Two hundred grams of the crude enzyme powder were suspended in 2 liters of distilled water at room temperature and adjusted to $\mathrm{pH} 4.0$ with $1 \mathrm{~N} \mathrm{HCl}$. The enzyme solution was stirred gently with a magnetic stirrer for $2 \mathrm{hr}$. Then the enzyme solution was centrifuged at $8,000 \mathrm{rpm}$ for $20 \mathrm{~min}$. The supernatant was dialyzed against 60 liters of $0.05 \mathrm{M}$ Tris- $\mathrm{HCI}$ buffer ( $\mathrm{pH} 8.0$ ) at $5^{\circ} \mathrm{C}$ for $48 \mathrm{hr}$. After being centrifuged at $8,000 \mathrm{rpm}$ for $10 \mathrm{~min}$, the supernatant was purified 216-fold of specific activity by means of DEAE-Cellulose, DEAE-Sephadex A-50, CM-Sephadex C-50 and Sephadex G-200 column chromatography. The recovery of the activity was 30,0 . The purified lipase was confirmed to be homogeneous with disc ele-

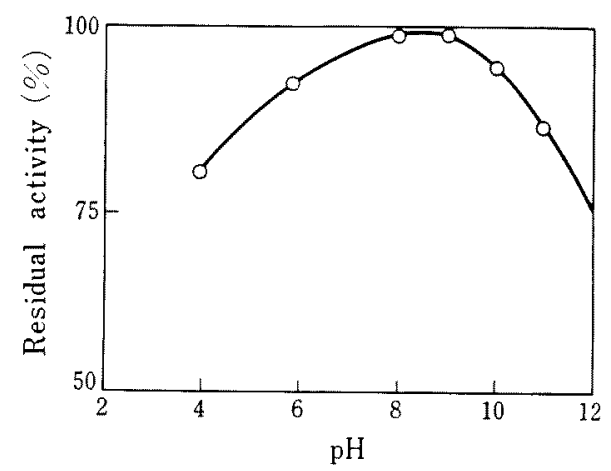

Frg. 2. pH Stability of Humicola Lipase.

The enzyme was dissolved in various buffer solutions (Macllvaine buffer, $\mathrm{pH} 4.0 \sim 8.0$; ammonium buffer $\mathrm{pH} 8.0 \sim 11.0$ ), and the solutions were incubated at $45^{\circ} \mathrm{C}$ for $1 \mathrm{hr}$. Residual activities were measured in a polyvinyl alcohol emulsified olive oil system at $45^{\circ} \mathrm{C}, \mathrm{pH} 8.0$. ctrophoresis and ultracentrifugal analysis (Fig. 1). The average molecular weight of the Humicola lipase was given as 27,500 \pm 500 by Archibald's $^{12 i}$ and Andrew's ${ }^{131}$ methods. $\alpha$ Helix content was estimated to be $18.90^{\circ}$ according to circular dichroism analysis. ${ }^{21}$ Sugar and lipid were not detected. The purified lipase was stable in the $\mathrm{pH}$ range from 4.0 to 11.0 (Fig. 2). The optimal $\mathrm{pH}$ for the hydrolysis of polyvinyl alcohol-emulsified olive oil was 8.0 and the optimal temperature was $60^{\circ} \mathrm{C}$. The purified lipase was stable up to $60^{\circ} \mathrm{C}$ and retained $55 \%$ of full activity after heating at $70^{\circ} \mathrm{C}$ for $20 \mathrm{~min}$. (Fig. 3). When the purified thermostable lipase was stored in a frozen state for more than six months, the loss of the lipase activity was nearly negligible.

Although lipases from many different sources have been described, only a few of these has been investigated in detail. The main reason is that these lipases are very difficult to be purified and hence satisfactory informations on the lipase action can not be obtained. Furthermore, many investigators have been bothered with the fact that these purified lipases are very unstable and lose their activity within a short period. As shown in Fig. 3, the thermostability of Humicola lipase was excellent.

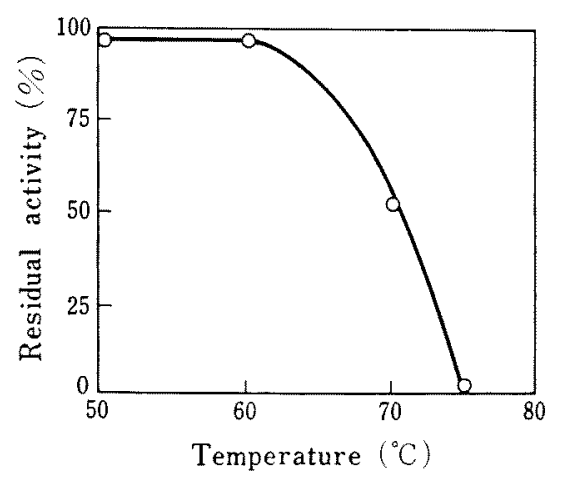

FIG. 3. Heat Stability of Humicola Lipase.

The enzyme was dissolved in $\mathrm{Tr}$ is- $\mathrm{HCl}$ buffer of $\mathrm{pH} 8.0$ and incubated at various temperatures for $20 \mathrm{~min}$. Residual activities were measured as described in Fig. 2. 
It is obvious that the thermostable property of Humicola lipase is useful not only for industrial purposes but also for attempts to obtain more information on the structure and function of lipase.

Details of the full investigation will be published elsewhere in the near future.

Authors are deeply grateful to Dr. Junta Sugiyama, Department of Botany, the University of Tokyo, for his valuable advices in the identification of the thermophilic fungus. Thanks are also due to Drs. Makiri Yamasaki, Takeshi Uozumi and Takashi Saiki, Department of Agricultural Chemistry, the University of Tokyo, for many valuable discussions and suggestions.

\section{REFERENCES}

1) J. B. Manning and L. L. Campbell, J. Biol. Chem, 236, 2952 (1961).

2) K. Ogasahara, A. Imanishi and T. Isemura, $J$. Biochem., 67, 65 (1970).

3) S. Endo, J. Ferment. Tech., 40, 346 (1962).

4) K. Mizusawa, E. Ichishima and F. Yoshida, Agr. Biol. Chem., 28, 884 (1964).
5) J. Fukumoto, M. Iwai and I. Tsujisaka, J. Gen. Appl. Microbiol., 9, 353 (1963).

6) J. Fukumoto, M. Iwai and Y. Tsujisaki, ibid, 10, 257 (1964).

7) K. Yamada and H. Machida, Nippon Nogeikagaku Kaishi, 36, 858 (1962).

8) R. C. Lawrence, T. T. Fryeer and B. Reiter, J. Gen. Micrabiol., 48, 401 (1967).

9) K. Nagaoka, Y. Yamada and I. Koaze, Agr. Biol. Chem., 33, 299 (1969).

10) Y. Satomura. S. Oi and A. Sawada, Bull. Agr. Chem, Soc. Japan, 22, 194 (1958).

11) I. Satomura, S. Oi, A. Sawada and J. Fukumoto, ibid., 23, 150 (1959).

12) H. K. Schachman, "Method of Enzymology," Vol. IV, Academic Press Inc., New York, N. Y., 1957, p. 32.

13) P. Andrew, Biochem. J., 91, 222 (1964).

Kei ARIMA

Wen-Hsiung LIU

Teruhiko BEPPU

Department of Agricultural Chemistry,

The University of Tokyo,

Bunkyo-ku, Tokyo

Received January 28, 1972 